I. V. Novitskyi, Dr. Sc. (Tech.), Prof., Dnipro University of Technology, Dnipro, Ukraine, email: orcid.org/0000-0002-8780-6589, V.V.Sliesarev, Dr. Sc. (Tech.), Prof., orcid.org/0000-0002-1058-5183, A. V. Maliienko, Cand. Sc. (Tech.), orcid.org/0000-0002-3165-9233

\title{
METHOD OF IDENTIFICATION OF NONLINEAR DYNAMIC CONTROL OBJECTS OF PREPARATORY PROCESSES BEFORE ORE DRESSING
}

Purpose. To develop a method for identifying mathematical models of control objects as a part of an adaptive management system for preparatory processes before ore processing.

Methodology. The methodological ground of the research is the classic position and the fundamental works by foreign and domestic scholars, statistics, and the results of authors' research. Methods of fuzzy set theory, comparative analysis of abstraction, and generalization of scientific experience of modern theoretical research studies, systematic and comprehensive approach are applied in the study. The effective operation of industrial technological complexes characteristic of the mining and processing industry involves solving a wide range of operational automatic control tasks.

Findings. Technological processes of reducing material coarseness such as crushing, grinding are the most resource-intensive operations of the mining and processing industry. Therefore, the use of the most effective systems of operational management of these processes is essential in modern conditions of operation of a mining and processing enterprise. A methodological approach to assessing the parameters of the linear parts of the control object model from the input parameters and the correspondence of the process values at the output of the control object are proposed. The analysis made it possible to determine and implement a management system for ore-shingle mills at an industrial enterprise.

Originality. For the first time, the study proposes to solve the main problems of identifying the corresponding structure of a real object and the structure of a model, determining the nonlinear static characteristics of an object. This allows one to create effective systems with a fairly universal method for identifying the control object.

Practical value. The method is distinguished by high rate of selection of information about an object. It allows determining the parameters of the linear parts and the structure of the nonlinear part of the model. The identification method described in the article was tested when developing and implementing control systems for ore-peeling mills IWG $55 \times 75$ at SevGOK MPP.

Keywords: identification method, nonlinear and non-stationary control object, adaptive systems, mining and processing integrated plant

Introduction. Crushing and grinding are widely spread technical processes for ore processing [1]. That is why effective operation control of these processes is a vital task. However, there are essential difficulties in solving this problem, since crushers and drum mills are considered nonlinear and nonstationary control objects, which are characterized by the substantial time response. Moreover, useful information signals about these control objects are exposed to high frequency noises. In such conditions, it is expediential to apply adaptive control systems. State-of-the-art means of information processing and control provide implementation of control algorithms practically of any degree of difficulty in real time scale, and the main challenge in performing adaptive control is to meet the conditions of quasi-stationarity.

Given these considerations, identification method of preparatory processes control should meet the following requirements:

1) provide high rate of selecting operational information about an object;

2) have versatile features as regards to the object structure;

3) take into consideration nonlinear elements as a part of the object;

4) exhibit characteristics of weak-signal sensitivity to interference actions.

Literature review. Effective exploitation of industrial and technical complexes typical for mining and processing industry involves solutions of a wide range of automatic operation control tasks, wherein identification of dynamic non-stationary control objects is one of them.

Many classic works are concerned with solving this task, among which are those written by P. Eykhoff, A.Sage, L.A. Rastrygin, D. Grop, N.S. Raibman and others. Though, all the calculating procedures described in the works are based

(C) Novitskyi I. V., Sliesarev V. V., Maliienko A. V., 2020 on strict limitations performing of which in practical conditions of processing mills are considered impossible [2].

Many known engineering methods such as processing of acceleration curve-fitting are oriented on the linear models of low order. As to non-parametric models such as patch models [3] or neuron nets [4], being versatile in the sense of their structure, they demand significant time for adjusting, which makes them of low use for identification inertial non-stationary objects [5]. At the same time, it is known that crushing and grinding facilities as controlled objects are considered nonlinear, non-stationary and highly inertial objects [6]. That is why in such conditions successful solving of identification tasks is possible on the basis of merging strict mathematical methods of information processing with engineering approaches to forming initial data that has brought to the approach described in this paper [7].

Problem description. A mathematical model of an object for the definite control channel (e.g. for a drum mill, selfgrinding for channel "speed of a feeder belt - active power of a driving motor") is given as the following scheme (Fig. 1).

In the scheme: $W_{1}\left(a_{1}, a_{2}, \ldots, a_{n}\right)$ is a linear operator dependent on $\mathrm{n}$ parameters $a_{1}, a_{2}, \ldots, a_{n}$, demonstrating inertial characteristics of the performing mechanism and the object; $\varphi$ $(x)$ is a nonlinear chain without inertia; $W_{2}\left(b_{1}, b_{2}, \ldots, b_{m}\right)$ is a linear operator dependent on the parameters $b_{1}, b_{2}, \ldots, b_{m}$ and demonstrating inertial characteristics of the control object, channels of gathering and transmitting information. It is assumed that the order of linear operators $W_{1}$ and $W_{2}$ is known.

When performing processes $u(t)$ and $z(t)$ on object input and output given in the interval $0 \div T$, it is required to identify parameters of linear parts $a_{l} l=\overline{1, n} ; b_{k} k=\overline{1, m}$ and the form of nonlinear function $\varphi(\mathrm{x})$.

Solution procedure. The principle which forms the basis for solving the task set, is that parameters of linear parts of the 


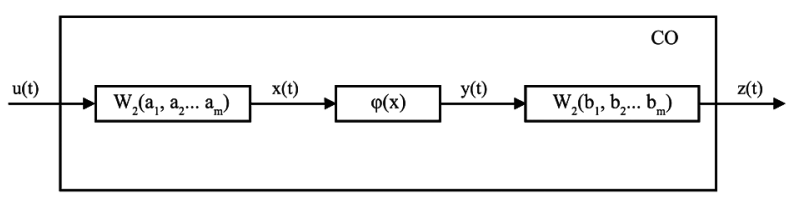

Fig. 1. Structural scheme of the controlled object

model $a_{l} l=\overline{1, n} ; \quad b_{k} \quad k=\overline{1, m}$ should have the values whereas the same values of process $x(t)$ correspond to the same values of process $y(t)$. For the given values of the parameters $a_{l}$ $l=\overline{1, n} ; \quad b_{k} k=\overline{1, m}$, processes $x(t)$ and $y(t)$ can be obtained by transformations of known $u(t)$ and $z(t)$, i.e.

$$
x(t)=W_{1}\left(a_{1}, a_{2} \ldots . a_{n}\right) \cdot u(t) ; \quad y(t)=W_{2}^{-1}\left(b_{1}, b_{2} \ldots . b_{m}\right) \cdot z(t) .
$$

After discrete time sampling, the degree of correspondence of the values of processes $x(t)$ and $y(t)$ can be done with the help of sample correlation ratio $\eta_{x y}$. Thus, the solution of the task of identification reduces to optimization problem

$$
\eta_{x y} \rightarrow \max _{a_{l} b_{k}}
$$

It is required to identify such values of parameters $a_{l}$ $l=\overline{1, n} ; \quad b_{k} \quad k=\overline{1, m}$ that sampling correlation ratio $\eta_{x y}$ will reach its maximum.

Problem solving. Before solving the problem (1), stated references of implementation of the processes $u(t), z(t)$ given within the interval $0 \div T$ have the form of discrete equidistant reports $u_{i}, z_{i} i=1, p$ with time-based step $\Delta t=T / p$, and operating range of change of process $x(t)$ is divided into $S$ intervals (groups) with step $h=\left(x_{\max }-x_{\min }\right) / S$. Let us set $x_{j} j=\overline{1, S}$ as a midpoint of the $j^{\text {th }}$ interval, where $\mathrm{j}$ is an interval (group) number.

Then, the problem of identification is solved following the given algorithm:

1. Some initial values of the parameters $a_{l} l=\overline{1, n} ; \quad b_{k}$ $k=\overline{1, m}$ are set.

2. The process of transformation of discrete process $u_{i}$ is done by operator $w_{i}$

$$
x_{i}=W_{1}\left(a_{1}, a_{2}, \ldots, a_{n}\right) \cdot u_{i}, \quad i=\overline{1, p} .
$$

3. Inverse transformation of discrete process $z_{i}$ is done by operator $W_{2}^{-1}$

$$
y_{i}=W_{2}^{-1}\left(b_{1}, b_{2}, \ldots, b_{m}\right) \cdot z_{i}, \quad i=\overline{1, p} .
$$

4. Obtained massif $y_{i} i=\overline{1, p}$ is divided into $S$ groups which correspond to the intervals $x_{j} j=\overline{1, S}$.

5. For each $j^{\text {th }}$ group $(j=\overline{1, S})$, a group mean $\bar{y}_{j}$ and dispersion $D_{j}$ are calculated.

6. Intergroup, general dispersion and sampling correlation ratio $\eta_{x y}$ are calculated.

7. Calculations according to points $2-6$ are repeated for each new values of parameters $a_{l} l=\overline{1, n} ; b_{k} k=\overline{1, m}$ until for a certain optimal set of parameters $a_{1}^{*}, a_{2}^{*}, \ldots, a_{n}^{*}, b_{1}^{*}, b_{2}^{*}, \ldots, b_{m}^{*}$, the maximum value of sampling correlation ratio $\eta_{x y}$ has been obtained.

The obtained optimal values of parameters $a_{1}^{*}, a_{2}^{*}, \ldots, a_{n}^{*}$, $b_{1}^{*}, b_{2}^{*}, \ldots, b_{m}^{*}$, which provide maximum $\eta_{x y}$, will be the result of identification. Besides, correlation of class marks $x_{j} j=\overline{1, S}$ and group mean $\bar{y}_{j} j=\overline{1, S}$, with optimal values $a_{1}^{*}, a_{2}^{*}, \ldots, a_{n}^{*}$, $b_{1}^{*}, b_{2}^{*}, \ldots, b_{m}^{*}$, is considered an estimate of non-linear static characteristic $y=\varphi(x)$ (Fig. 1).
The process of finding parameters $a_{1}, a_{2}, \ldots, a_{n}, b_{1}, b_{2}, \ldots$, $b_{m}$ is carried out by one of the optimization methods (for example, by the method of descent in coordinates, and when the amount of parameters is small, by the method of simple search).

It is obvious that when performing the identification procedure, there is a need to provide adequate variability of the input action on object $u(t)$, preferably throughout the whole operating range of its change.

Besides, process $u(t)$ in the interval $0 \div T$ should contain the repeated value of the input action, for example, as given in Fig. 2, $a$.

Otherwise, as given in Fig. 2, $b$, as an example, the problem will have a set of solutions since for any parameter set $a_{1}$, $a_{2}, \ldots, a_{n}, b_{1}, b_{2}, \ldots, b_{m}$ an intergroup dispersion will be close to zero, and selective correlation ratio - close to 1 . If there is any possibility to change the input action purposefully in the whole operating range, then the method can be activated by reducing time interval $0 \div T$ ( Fig. $2, b$ )

Fig. 3 demonstrates the scheme of the simulation experiment aimed at evaluating response of the described identification method to high frequency interferences being active at the output of an object.

To be specific, control object (CO) was a series connection of linear relaxation chains with transmitting functions

$$
W_{1}(p)=\left(a_{1} p^{2}+a_{2} p+1\right)^{-1} ; \quad W_{2}(p)=\left(b_{1} p+1\right)^{-1},
$$

and with static characteristics $y=c_{2} x^{2}+c_{1} x+c_{0}$. Action $u(t)$, which corresponds to Fig. 2, $b$, was applied to CO input. Interference action $f(t)$ was imitated on CO output. Therein, centered stable process $f(t)$ had high frequency (relatively to the

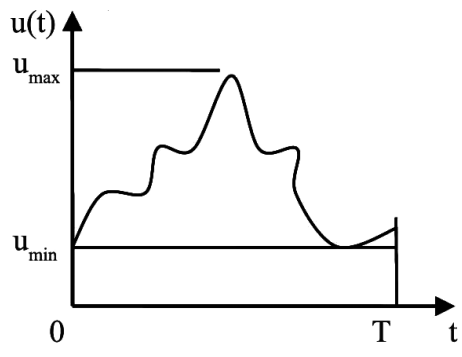

$a$
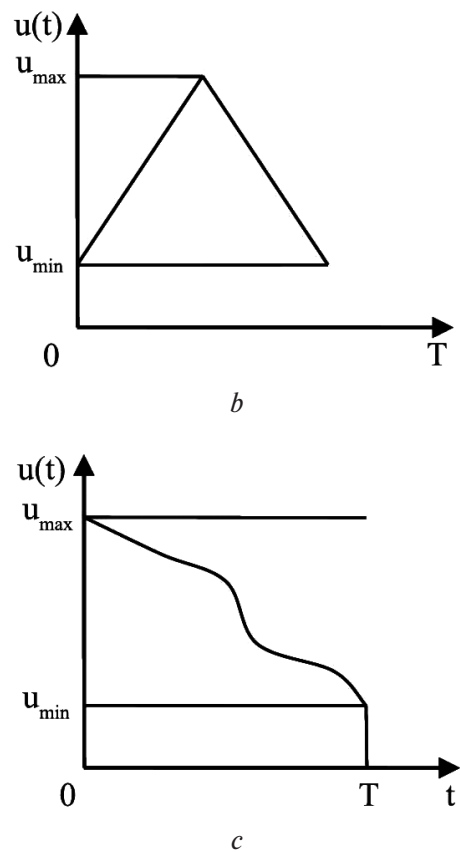

Fig. 2. Possible types of the input action on the object 


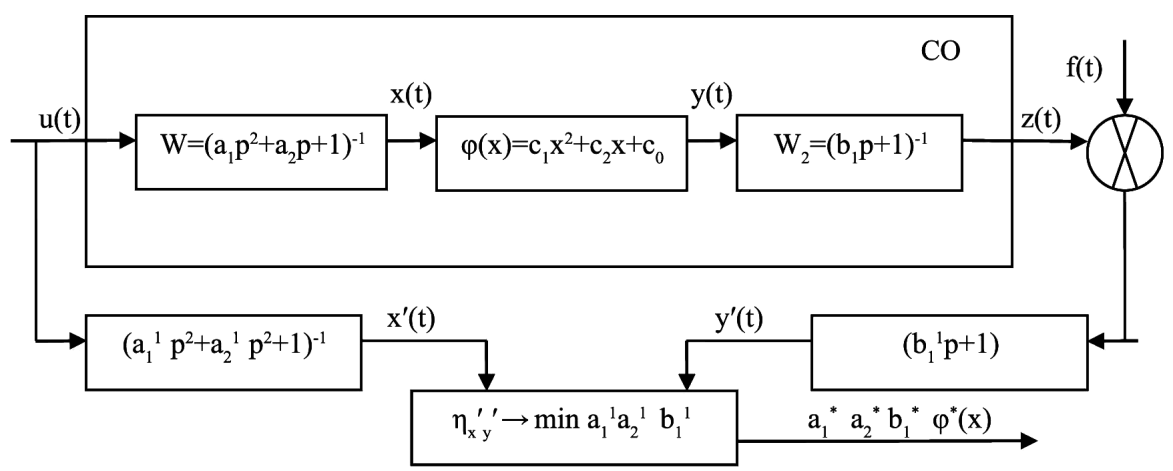

Fig. 3. Scheme of the simulation experiment

object's own frequency) broadband spectrum and saleable mean square deviation. As a result of the identification in accordance with the described algorithm, values of parameters $a_{1} a_{2} b_{1}$ were evaluated. Correspondent estimates are designated as $a_{1}^{*} a_{2}^{*} b_{1}^{*}$.

The dependence of parameter evaluation error $\delta=\frac{\left|a_{1}-a_{1}^{*}\right|}{a_{1}}+\frac{\left|a_{2}-a_{2}^{*}\right|}{a_{2}}+\frac{\left|b_{1}+b_{1}^{*}\right|}{b_{1}}$ on a mean square deviation of interference $\sigma_{j}$ obtained as a result of the experiment is given in Fig. 4. Herein, $\sigma_{f}$ which characterizes interference intensity is calibrated as a percentage of the whole range of changes $z(t)$ in the monitored interval $0 \div T$

The obtained dependence (Fig. 4) demonstrates that the identification method is applicable when interference intensity is up to $7 \%$ from the entire range of output signal that is an evidence of its high-noise immunity.

Practical implementation. The identification method described in this paper was applied when developing and implementing control systems for mills of IWG (МРГ) $55 \times 75$ type in conditions of the Northern Mining and Processing Plant (MPP) "SevGOK" [8].

Experimental research on identification of the mills of МРГ $55 \times$ ' 75 type operating at stage 2 was done in the conditions of MPP "SevGOK". Therein, the object structure was accepted to be attributable to Fig. 5. During the experiment mean driver power $P$ and the signal from electronic filtering device $A_{f p}$ were fixed directly proportional to intensity of ore load variation. In accordance with the procedure described above, by controlling the feedstock the mill was fed with at the beginning and then discharged.

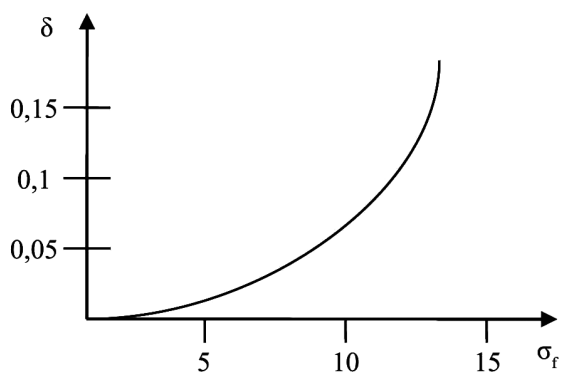

Fig. 4. Dependence of the relative inaccuracy of the method $\delta$ on intensity $\sigma_{f}$

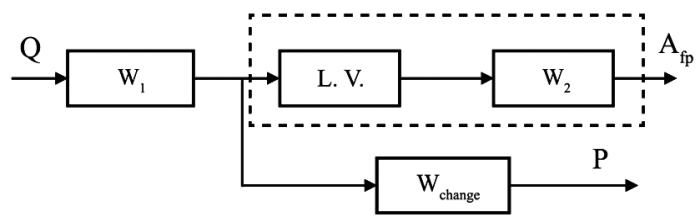

Fig. 5. Enlarged schematic structure of the identification object
The processes of signal change $P(t)$ and $A(t)$ fixed therein are given in Figs. 6, 7. Thus, signal of mean power $P$ was an argument for criteria $A$.

The main tasks of identification were as follows:

1. To identify structures of a real object relevant to the model structure (Fig. 1).

2. To identify nonlinear static characteristic of the object to use it in the obtained information about its structure when organizing optimal search of the criteria maximum.

3. To evaluate the response rate of the linear part of the model.

A prior assumption was that a structure of the slow-response part of the system (Fig. 5) corresponds to the simplest transfer function: $W_{2}=\left(T_{p}+1\right)^{-1}$. The processes $P(t)$ and $A_{f p}(t)$ were processed by electronic digital computer "ЭЦВМ" applying the program in accordance with the given above procedure. Fig. 6 demonstrates the results of identification of static characteristic $A_{f p}(P)$. The best coincidence of curves $A_{\mathrm{I}}(P)$ and $A_{\mathrm{II}}(P)$ has been reached through time constant of inertial part $T=2.38 \mathrm{~min}$. Divergence of curves $A_{\mathrm{I}}(P)$ and $A_{\mathrm{II}}(P)$ can be explained by change in coarseness of grading of the material inside the mill after embodiment of "feeding - discharge" cycle in the process of identification. The result of identification is static characteristic of nonlinear part $A^{*}(P)=\left[A_{\mathrm{I}}(P)+\right.$ $\left.+A_{\mathrm{II}}(P)\right] / 2$ shown by dashed line in Fig. 8 . In this case, estimate $\delta \int_{1.72}^{1.9}\left\{\left[A^{*}(P)-A_{I}(P)\right]^{2} /(P)\right\}^{\frac{1}{2}} d P$ was 0.03 that is the

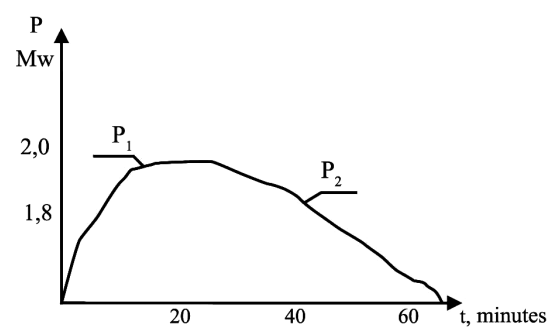

Fig. 6. Processes $P(t)$ obtained during the experiment done on the mill of MPГ $55 \times 75$ type at MPP "SevGOK"

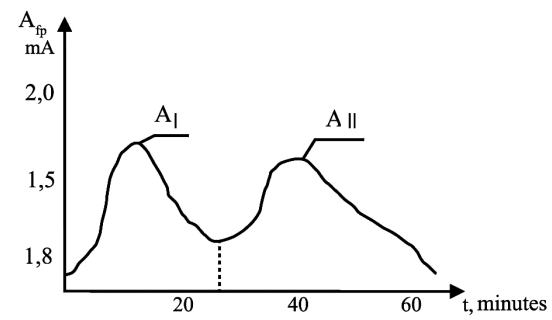

Fig. 7. Processes $A_{f p}(t)$ obtained during the experiment done on the mill of MPT $55 \times 75$ type at MPP "SevGOK" 


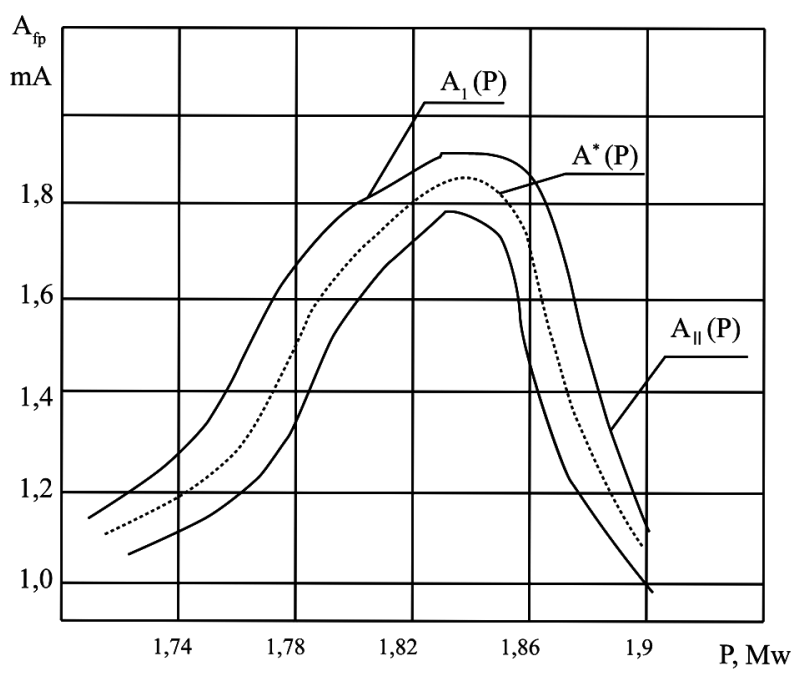

Fig. 8. Static characteristics of the mill of MPГ $55 \times 75$ type obtained as a result of identification

evidence of the correspondence of the chosen model structure to the real object.

The obtained dependence of the oscillation strength on mean power $A^{*}(P)$ can be used for computation a dependence of intensity on filling degree $\varphi$, if in its turn, dependence $P$ on $\varphi$ is known. For the mill of MPГ $55 \times 75$ type three measurements of the in-mill filling degree and correspondent to them values of mean power: $36 \%-1.700 \mathrm{kWt} ; 41.05 \%-1.836 \mathrm{kWt}$; $45.1 \%-1.890 \mathrm{kWt}$, were made. For these three measurements approximation of dependence $P(\varphi)$ were done within the range of filling: $36-45 \%$ by polynom of the second power, i. e. $P=a \varphi^{2}+b \varphi+c$, where $a=-1.2884 ; b=126.46 ; c=-1183$. This dependence $P(\varphi)$ is shown in Fig. 9 with the approximation assemblies. Now, using the dependences $A^{*}(P)$ shown in Fig. 8 and $P(\varphi)$ shown in Fig. 8 , there is no difficulty in obtaining dependence of oscillation intensity $A^{*}$ on filling degree $\varphi$ by excluding parameter $P$.

This dependence is given in Fig. 9. It has well expressed extremum - maximum. It is practically symmetric relatively an indefinite value of $\varphi^{*}$ and comparatively fast wanes with offsetting $\varphi$ from point $\varphi^{*}$. The obtained dependence $A^{*}(\varphi)$ was approximated by several curves of the appropriate form: $A_{1}=$ $=a \varphi^{2}+b \varphi+c-$ by the second order polynom; $A_{2}=\left(a \varphi^{2}+b \varphi+\right.$ $+c)^{-1}$, where $\Delta=4 a c-b^{2}>0-$ the function inverse to the second order polynom; $A_{3}=a^{3} /\left[(\varphi-b)^{2}+a^{2}\right]+c$, where $a>0$ - witch of Agnesi; $A_{4}=\frac{c}{\sqrt{2 \pi \sigma}} \cdot \exp \left[-(\varphi-M)^{2} / 2 \sigma^{2}\right]$ by the curve of frequency function of the normal law of distribution. The initial data were twelve points of the dependence $A^{*}(\varphi)$, i.e. pair $\left(A_{i} \varphi_{i}\right) i=\overline{1.12}$ (Fig. 10). The approximation problem was formed as follows

$$
J=\sum_{i=1}^{12}\left[A_{i}-f\left(a, b, c, \varphi_{i}\right)\right]^{2} \rightarrow \min _{a, b, c}
$$

where $f\left(a, b, c, \varphi_{i}\right)$ is a function approximating dependence $A^{*}(\varphi)$. For four functions listed above the minimal value of the criteria for the second order polynom was taken $J_{1}=431 \cdot 10^{-4}$, for the inverse function $-J_{2}=384 \cdot 10^{-4}, J_{3}=311 \cdot 10^{-4}$ for the witch of Agnesi; $J_{4}=254 \cdot 10^{-4}-$ for the normal law of distribution. As $\min \left(J_{1}, J_{2}, J_{3}, J_{4}\right)=J_{4}$, and taking into consideration the positive results of experimental dependence $A(\varphi)$ (Fig. 10) upon the criterion $x^{2}$ on correspondence to the normal law of distribution, we can assume that regularities of the formation of statistic dependence being monitored $A(\varphi)$ have stochastic nature.

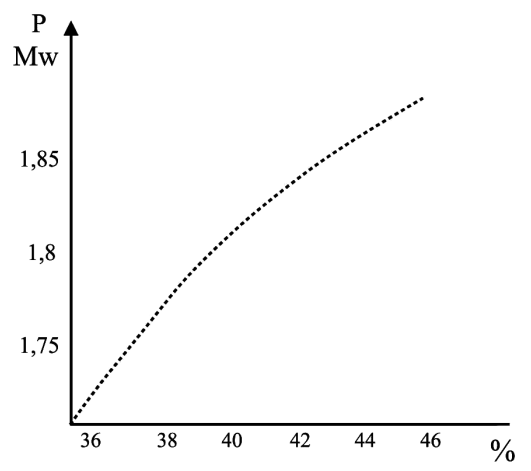

Fig. 9. Dependence of the mean power and optimization criterium $\varphi$

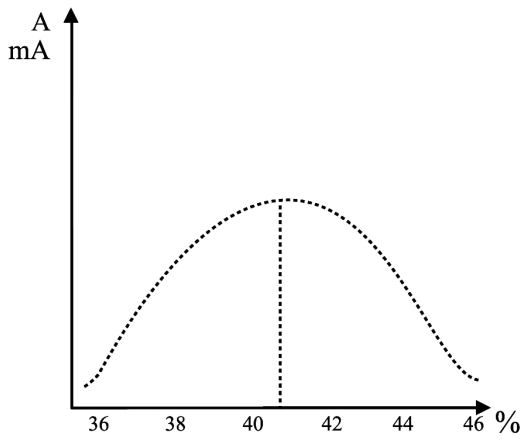

Fig. 10. Dependence of optimization criterium on the filling degree $\varphi$

Here, attention should be drawn to the results of the research given in [9], according to which there are parametric excitation of load fluctuations when the mill drum rotating. Moreover, it is shown that the fluctuations appear in a narrow range in the mill filling with the constant amplitude. At the same time, according to the research done with the considerations on random character filling in distribution diagram formation on the basis of multifrequent model, the analogous dependence is described by Gauss curve as that observed in practice $A(\varphi)$ (Fig. 10).

Conclusions. Technological processes for reducing the size of the material, such as crushing, grinding are the most resource-intensive operations of the mining industry. Therefore, the use of the most effective operational management systems for these processes is essential in the current conditions of the mining and processing enterprise. The purpose of this publication is to develop a method for identifying mathematical models of control objects as part of an adaptive control system for preparatory processes before ore dressing.

Unlike the existing methods requiring substantial computing power, the proposed technology uses immediate calculation which considerably reduces requirements to the computing.

Besides, the proposed technology ensures higher qualitative and quantitative indicators of the outcomes data processing, including:

- higher accuracy of delimitation;

- high stability of results.

The identification method presented in this paper is rather versatile. It suggests comparatively quick filtering information about an object and has good error-rate performance.

\section{References.}

1. Khomenko, O.E., Kononenko, N.N., Vladiko, O.B., \& Maltsev, D. V. (2011). Hirnichorudna on the right of Ukraine in the measure of Internet. Dnipropetrovsk: National Mining University. ISBN 978-966-350-306-6. 
2. Groves, P.D. (2013). Principles of GNSS, inertial, and multisensor integrated navigation systems. Artech House.

3. Li, A., Ivanov, N., \& Kuznetsov, P.M. (2014). Dynamic system identification on the basis of non-linear matrix transformation. Newsletter of UGATU, 18, 237-242.

4. Neusypin, K.A., Proletarskii, A. B., Vais, Yu. L., \& Sholokhov, D. O. (2012). Forming assembly of filtering criteria of compact algorithm of self-organisation. Automatization and modern technologies, (11), 14-16.

5. Tsibizova, T. Yu. (2015). Method of identification of nonlinear control systems. Contemporary problems of science and education, 1-1.

6. Pavlov, Yu. N., Nedashkovskyi, V. M., Tykhomirova, E.A., \& Shavyrin, I. B. (2014). Method of harmonic linearization in the problem of identification nonlinear dynamic systems. Science and education E-Journal, (4), 382-397.

7. Ljung, L. (2013). Some classical and some new ideas for identification of linear systems. Journal of Control, Automation and Electrical Systems, 24(1-2), 3-10.

8. Novitsky, I. V., \& Kostina, Ye. I. (2014). Method of nonparametric identification of nonlinear dynamic control objects of processing technology. Mining Electric Engineering and Automatization Scientific and Technical Collections, (92), 67-69. 9. Novitsky, I. V., \& Us, A. V. (2016). Adaptive system of controlling the coarse crushing process. Sistemnye tehnologii. Regional Educational Institution Collection of Scientific Papers, 4(105), 69-75.

\section{Метод ідентифікації нелінійних динамічних об'єктів керування підготовчими процесами перед збагаченням руд}

\section{I. В. Новицький, В. В. Слєсарєв, А. В. Малієнко}

Національний технічний університет «Дніпровська політехніка», м. Дніпро, Україна, e-mail: vvgnat@ukr.net

Мета. Розробка методу ідентифікації математичних моделей об’єктів керування у складі адаптивної системи управління підготовчими процесами перед переробкою руди.

Методика. Методологічною основою дослідження є класична позиція та фундаментальні праці закордонних і вітчизняних учених, статистика, результати авторських досліджень. У дослідженні застосовані методи теорії нечітких множин, порівняльний аналіз, абстракції та узагальнення наукового досвіду сучасних теоретичних досліджень, системний і комплексний підхід. Ефективна експлуатація виробничо-технологічних комплексів, що характерна для гірничо-збагачувальної промисловості, передбачає вирішення широкого кола завдань автоматичного управління.

Результати. Технологічні процеси зниження грубості матеріалу, такі як дроблення, подрібнення, $є$ найбільш ресурсоємними операціями гірничодобувної й переробної промисловості. Тому використання найбільш ефективних систем оперативного управління цими процесами необхідне в сучасних умовах експлуатації гірничо-збагачувального комбінату. Запропоновано методологічний підхід до оцінки параметрів лінійних частин моделі об'єкта управління за вхідними параметрами й відповідності значень процесу на виході об'єкта управління. Аналіз дозволив визначити та впровадити систему управління рудно-черепичними млинами на промисловому підприємстві.

Наукова новизна. Уперше в дослідженні пропонується вирішити основні проблеми ідентифікації відповідної структури реального об'єкта та структури моделі, визначення нелінійних статичних характеристик об’єкта. Це дозволяє створювати ефективні системи з досить універсальним методом ідентифікації об'єкта управління.
Практична значимість. Метод відрізняється високою швидкістю виділення інформації про об’єкт. Це дозволяє визначати параметри лінійних частин і структуру нелінійної частини моделі. Описаний у роботі метод ідентифікації був випробуваний при розробці та впровадженні систем управління рудно-шелушильними млинами IWG $55 \times 75$ в умовах Північний ГЗК БПП.

Ключові слова: метод ідентифікації, нелінійний $i$ нестаціонарний об'єкт управління, адаптивні системи, гірничо-збагачувальний комбінат

\section{Метод идентификации нелинейных динамических объектов управления подготовительными процессами перед обогащением руд}

\section{И. В. Новицкий, В. В. Слесарев, А. В. Малиенко}

Национальный технический университет «Днепровская политехника», г. Днепр, Украина, e-mail: vvgnat@ukr.net

Цель. Разработка метода идентификации математических моделей объектов управления в составе адаптивной системы управления подготовительными процессами перед переработкой руды.

Методика. Методологической основой исследования являются классическая позиция и фундаментальные труды зарубежных и отечественных ученых, статистика, результаты авторских исследований. В исследовании применены методы теории нечетких множеств, сравнительный анализ, абстракции и обобщение научного опыта современных теоретических исследований, системный и комплексный подход. Эффективная эксплуатация производственно-технологических комплексов, характерная для горнообогатительной промышленности, предполагает решение широкого круга задач автоматического управления.

Результаты. Технологические процессы снижения грубости материала, такие как дробление, измельчение, являются наиболее ресурсоемкими операциями горнодобывающей и перерабатывающей промышленности. Поэтому использование наиболее эффективных систем оперативного управления этими процессами необходимо в современных условиях эксплуатации горно-обогатительного комбината. Предложен методологический подход к оценке параметров линейных частей модели объекта управления по входным параметрам и соответствию значений процесса на выходе объекта управления. Анализ позволил определить и внедрить систему управления рудно-черепичными мельницами на промышленном предприятии

Научная новизна. Впервые в исследовании предлагается решить основные проблемы идентификации соответствующей структуры реального объекта и структуры модели, определения нелинейных статических характеристик объекта. Это позволяет создавать эффективные системы с достаточно универсальным методом идентификации объекта управления.

Практическая значимость. Метод отличается высокой скоростью выделения информации об объекте. Это позволяет определять параметры линейных частей и структуру нелинейной части модели. Описанный в работе метод идентификации был опробован при разработке и внедрении систем управления рудно-шелушильными мельницами IWG $55 \times 75$ в условиях СевГОК МПП.

Ключевые слова: метод идентификации, нелинейный и нестационарный объект управления, адаптивные системы, горно-обогатительный комбинат

Recommended for publication by V.Tkachev, Doctor of Technical Sciences. The manuscript was submitted 23.05.19. 